Society of Radiographers are to be asked to send one representative each to serve on the committee. This committee was given power to elect its own chairman and to formulate a constitution for the Group. In addition to providing a medium for the exchange of views and experiences on the practice of radiography and $\mathrm{X}$-ray crystallography in industry, it is to be hoped that the Group may ultimately issue a report summarizing many of the essential practical points of importance to users of X-ray plant, as one noticed at the above-mentioned Conference that many quite elementary matters of technique were not generally known in the various industries employing X-rays. Membership of the Industrial Radiology Group is open to all who are interested, whether or not they are at present members of the Institute of Physics.

\section{Association of Scientific Workers}

THE annual council meeting of the Association of Scientific Workers was held in Birmingham on May 24 and 25 ; eighty delegates were present representing scientific workers and engineers in industrial and Government posts as well as university staff and students. As this was the first council meeting to be held since the registration of the Association as a trade union, the reports presented, and the ensuing discussion, were chiefly concerned with the planning of an industrial policy for the Association. Discussion centred mainly around a report by the Industrial Sub-Committee which analysed the present conditions of scientific and engineering staff. This report showed that even under peace-time conditions, there is a considerable difference between salaries paid to people having the same qualifications but employed by different firms. In the engineering industry, for example, the general salary level is notably less than in certain chemical firms. Increments were often obtained by negotiation between the employer and the individual, but war-time restrictions on change of employment have removed the individual's chief bargaining instrument. A survey among members of the Association shows that there is a marked tendency in industry for no increments to be given, while in Government establishments war-time posts carry a fixed salary.

It was pointed out in the discussion that cancellation of increments is particularly unfair to the younger scientific workers whose salaries are frozen at the low starting figure. Attention was also directed to the injustices caused by failure to grant payment for overtime to many scientific workers and engineers. It was said to be a common experience, particularly in large firms, for hours of work and holidays to be altered suddenly without consultation with the unorganized sections of the staff. The conclusion drawn by the Industrial Sub-committee of the Association and endorsed by the council meeting is that collective action through the Association is the only effective method by which engineers and scientific workers can safeguard their conditions, and bring them into relationship with those of organized sections of industry: The council unanimously adopted a resolution in favour of close co-operation between the Association and other trade unions.

\section{Mummification in America}

Reference has already been made (NAture, April 5, p. 413) to the first part of a description by Dr. Aleš Hrdlička, curator of physical anthropology in the U.S. National Museum, of investigations undertaken in mummy caves and rock shelters in the Aleutian Islands off the coast of Alaska (Scientific Monthly, Jan.-Feb. 1941). It would appear that. the aboriginal inhabitants were at some unknown period replaced by the Aleuts, among whom, comparatively lately, Russian penetration took place. The Aleuts practised mummifying, though whether they began to do so after their arrival in the islands. or whether they brought the custom with them from their unknown place of origin remains a mystery. The mummies of both sexes were stored in the caves lying upon driftwood, and differences of physical anthropology among them suggest that a few members of the pre-Aleut people had been allowed to survive, perhaps in a condition of slavery. The finding of one or two objects of Russian origin with some of the mummies seems to indicate that the practice continued until a fairly recent date. A certain amount of cremation also appears to have been customary, and interesting and well-developed industries showing some degree of artistry were collected. The difficulties under which the expedition worked were very considerable, but nevertheless much valuable information has been added to our knowledge of these interesting peoples.

The practice of mummifying the dead, like that of trephination, is always intriguing. Why should these elaborate processes have been undertaken at all ? Connected as they often were with magic or religious. notions, their discovery sometimes throws a sidelight on the ideas of bygone peoples; whereas a study of the ordinary industries of such folk only determines their material culture--only tells us how they lived, not how they thought. Actually, mummifying has never been a common method of dealing with the dead either in modern or in ancient times. Egypt, of course, furnishes the classic example, but in the New World there were peoples both in South and North America who practised the rite. The orthodox diffusionist naturally claims that the custom in, say, Peru derived from Egypt; but frankly it is difficult to believe that the two or three prehistoric American peoples really had any connexion either with the Old World or with each other. It would seem far more likely to have been the result of a spontaneous development consequent upon a somewhat similar outlook on death.

\section{Floating Electric Power Plants}

Mr. A. C. Hardy, in an article entitled "The Electric Ship" in the Electrician of May 2, outlines. some recent trends and developments. A project for a $50,000 \mathrm{kw}$. self-contained, floating power plant. 
is being studied by the General Electric Co., Schenectady. The plant is to be housed in a hull of similar dimensions to that of a Great Lakes freighter capable of passing through the Welland Canal, the dimensions being limited to $290 \mathrm{ft}$. by $43 \mathrm{ft}$., with a draught of $10 \mathrm{ft}$. and a low-bridge clearance of $15 \mathrm{ft}$. It is recalled that this idea is not new, for two $10,000 \mathrm{kw}$. turbo-generators were installed in the hull of the Jacona, a vessel built during the War of 1914-18, and since 1930 used as a floating power plant in New England. This vessel was taken in hand at the works of the Newport News Shipbuilding and Dry Dock Co. The main engine boilers and auxiliary formerly used for propulsion were removed. The funnel, foremast and four forward winches, propeller, shaft-tunnel and shafting were removed. New watertight bulkheads were installed fore and aft, and special thickening was fitted underneath the power plant. Two steam turbo-generators were installed, taking steam from four marine boilers, delivering $280,000 \mathrm{lb}$. of steam per hour at $425 \mathrm{lb}$. pressure at $250^{\circ} \mathrm{F}$. superheat. The steam consumption of the turbines is about 9.4 lb. per $\mathrm{kwh}$. at full load, the turbines being directly connected. With the exception of a few auxiliaries, the whole of the plant is divisible into two separate units, two boilers being arranged to serve each turbine. The method of making electrical connexion to the shore is a problem involving considerable study.

\section{James Nasmyth as Tool Maker}

When James Nasmyth (1808-1890) was twentysix years of age he set up in business as an engineer in Manchester, and two years later, at Patricroft on the Bridgewater Canal, he established the famous Bridgewater Foundry, so named after the Great Duke. By 1856, Nasmyth was able to retire and devote himself to astronomy. The foundry, however, was carried on successfully by others until July 1940 . when it became a Government ordnance factory. One consequence of this was the presentation to the Institution of Mechanical Engineers, by Sir Holberry Mensforth, of Nasmyth's well-known "Sketch Book" and a portfolio of early drawings. Most of the drawings are of steam hammers, but others relate to machine tools. Some of these are of exceptional interest, and in The Engineer of May 23, Dr. H. W. Dickinson gives a review of Nasmyth's pioneering work in this department of engineering. As an appendix to the article a transcription is given of a letter written in 1864, in which Nasmyth refers to his discovery of the 'willow leaf' pattern on the sun's surface, a discovery which "has made a great stir among astronomers".

\section{Activated Charcoals from Peat Residue}

IN the tenth part of a series of "Studies in Peat", J. Reilly and J. R. O'Donoghue (Sci. Proc. Roy. Dublin Sor., 22 (N.S.), 367 ; 1941) report experiments on the preparation of activated charcoals from peat. Before preparing the charcoal, waxy constituents were removed. Of various methods used, activation with superheated steam, and, to a lesser extent, by treatment with syrupy phosphoric acid before carbonization were found to be best for producing charcoals of performance approaching commercial standards. So far as is known, the peat residue is the first substance of Irish origin to be examined as a source of active charcoal.

\section{Earthquakes in Turkey}

That the earth's crust has not yet settled down after the disastrous Turkish earthquakes of December 1939 is evidenced by recent earthquake activity in that country. Minor shocks are frequently experienced, and stronger ones occur from time to time. Two such happened during the last fortnight. A strong earthquake on May 24 broke the sea wall at Mugla, opposite the island of Rhodes. Some other damage and twenty casualties have been reported at Mugla, and less intense shocks were experienced at Smyrna. During the night of May 30-31, a strong tremor was felt in Anatolia, causing serious damage to a large number of houses. No casualties have been reported as a result of this shock.

\section{Announcements}

Prof. L. J. Mordel, F.R.S., Fielden professor of pure mathematies in the University of Manchester, has been awarded the De Morgan Medal of the London Mathematical Society.

DR. J. A. VENN, president of Queens' College, Cambridge, and Gilbey lecturer in agricultural economics and history, has been elected vice-chancellor of the University for the academical year beginning on October 1, in succession to Mr. E. A. Benians, master of St. John's College, who has held the office for the customary two years.

The Adams Prize for 1939-40, valued at about $£ 268$, has been awarded to Dr. Harold Davenport, assistant lecturer in mathematics in the University of Manchester. Dr. Davenport, who graduated as a wrangler, was formerly a fellow of Trinity College.

The herbarium near Hudiksvall, in Sweden, containing thirty thousand specimens of roses, compiled and classified by the late Reinhold Matsson, the Swedish botanist, has been destroyed by a fire.

A NEW division of chemotherapy has been formed in the National Institute of Health of the United States Public Health Service to be under the direction of Dr. William H. Sebrell, jun. The new unit will be concerned with research on sulphanilamide products and with new synthetic drugs with antimalarial properties, in order to make the United States independent of the Dutch East Indies supply of quinine. The division will have quarters at the National Institute of Health in Bethesda, Maryland. The building will also be the headquarters of the divisions of chemistry and zoology.

Erratum. The title of the letter by Dr. H. L. A. Tarr in Nature of April 5, p. 417, should read "The Bacteriostatic Action of Nitrites"; thus the work relates to "nitrites" and not to "nitrates" as printed. 